\title{
ANALYSIS OF ASSOCIATIONS OF POLYMORPHISMS IN THE GENES CODING FOR L4, IL10, IL13 WITH THE DEVELOPMENT OF ATOPIC BRONCHIAL ASTHMA AND ITS REMISSION
}

Zhorina YuV ${ }^{1 凶}$, Abramovskikh OS ${ }^{1}$, Ignatova GL¹, Ploshchanskay $\mathrm{OG}^{2}$

South Ural State Medical University, Chelyabinsk, Russia

2 DNA Clinic LLC, Chelyabinsk, Russia

Bronchial asthma is a multifactorial disease underpinned by chronic inflammation. The atopic phenotype of BA implies the presence of similar molecular mechanisms of pathogenesis between the patients. The aim of this study was to analyze the associations between the development of atopic BA/its remission and the following polymorphisms of interleukin genes: IL4 (rs2243250; C-589T), IL10 (rs1800896; G-1082A; rs1800872; C-592A), and IL13 (rs20541; Arg130GIn). Using allelespecific polymerase chain reaction (PCR), we studied the listed SNPs in the mixed urban sample of patients with BA $(n=53)$ and the controls $(n=30)$ residing in South Ural. The analysis revealed that genotype AA of IL10 (rs1800872) occurred more frequently in the control group (23.3\%) than in the patients with atopic BA (5.7\%) $(\mathrm{OR}=0.197 ; 95 \% \mathrm{Cl}$ [0.047-0.832]; $p=0.031)$. No differences in genotype frequencies were observed between the patients with atopic BA and the controls for other studied polymorphisms. Our study failed to demonstrate the association of the listed polymorphisms and BA remission.

Keywords: bronchial asthma in adults, atopy, remission, gene polymorphism, cytokines

Author contribution: Zhorina YuV — conceived and planned the study, collected, processed and interpreted the data, performed statistical analysis, participated in writing the manuscript; Abramovskikh OS - proposed the method and supervised the study, analyzed and interpreted the data, participated in writing the manuscript; Ignatova GL — analyzed the clinical data, supervised the study, interpreted the data, participated in writing the manuscript; Ploshchanskay OG collected the data, conducted laboratory tests, interpreted the data and participated in writing the manuscript.

Compliance with ethical standards: the study was approved by the Ethics Committee of South Ural State Medical University (Protocol № 10 dated November 17 , 2016). The patients gave informed consent to participate in the study.

Correspondence should be addressed: Yulia Yu. Zhorina Vorovskogo, 64, Chelyabinsk, 454092; juliamart24@mail.ru

Received: 25.09.2019 Accepted: 11.10.2019 Published online: 21.10.2019

DOI: $10.24075 /$ brsmu.2019.067

\section{АНАЛИЗ СВЯЗИ ПОЛИМОРФНЫХ ВАРИАНТОВ ГЕНОВ IL4, IL10, IL13 С РАЗВИТИЕМ АТОПИЧЕСКОЙ БРОНХИАЛЬНОЙ АСТМЫ И РЕМИССИЕЙ}

Ю. В. Жорина ${ }^{1}$, О. С. Абрамовских ${ }^{1}$ Г. Л. Игнатова' ${ }^{1}$ О. Г. Площанская²

1 Южно-Уральский государственный медицинский университет, Челябинск, Россия

2 ООО «ДНК Клиника», Челябинск, Россия

Бронхиальная астма (БА) является многофакторным заболеванием, в основе которого лежит хроническое воспаление. Атопический фенотип предполагает наличие у пациентов сходных молекулярных механизмов патогенеза. Целью работы было провести анализ ассоциации полиморфных локусов генов IL4 (rs2243250; C-589T), IL10 (rs1800896; G-1082A; rs1800872; C-592A), IL13 (rs20541; Arg130G/n) с развитием атопической БA и ремиссией. С помощью аллель-специфичной полимеразной цепной реакции (ПЦР) проведено исследование полиморфных локусов генов больных БА ( $n=53)$ и группы сравнения ( $n=30)$, смешанной городской выборки, проживающих на Южном Урале. Анализ ассоциации полиморфных вариантов генов интерлейкинов с развитием БА показал, что генотип AA IL10 (rs1800872) встречается чаще в группе сравнения (23,3\%), чем в группе атопической БА $(5,7 \%)(О Ш=0,197 ; 95 \%$ ДИ [0,047-0,832]; $p=0,031)$. Для остальных исследованных полиморфных локусов генов интерлейкинов отличий в частотах генотипов между больными атопической БА и группой сравнения не обнаружено. Не удалось показать влияние изученных полиморфных локусов на развитие ремиссии заболевания.

Ключевые слова: бронхиальная астма у взрослых, атопия, ремиссия, полиморфизм генов, цитокинь

Информация о вкладе авторов: Ю. В. Жорина - общая идея и методология исследования, сбор, обработка и интерпретация данных, статистический анализ, написание и оформление статьи; О. С. Абрамовских - методика и курирование исследования, анализ и интерпретация данных, написание и оформление статьи; Г. Л. Игнатова - анализ клинической части данных, курирование исследования, интерпретация данных, написание статьи; О. Г. Площанская - сбор данных, осуществление лабораторного этапа обследования, интерпретация данных, написание статьи.

Соблюдение этических стандартов: исследование одобрено этическим комитетом ФГБОУ ВО «ЮУГМУ Минздрава» (протокол № 10 от 17 ноября 2016 г.). Все участники подписали добровольное информированное согласие на участие в исследовании.

$凶$ Для корреспонденции: Юлия Владимировна Жорина ул. Воровского, д. 64, г. Челябинск, 454092; juliamart24@mail.ru

Статья получена: 25.09.2019 Статья принята к печати: 11.10.2019 Опубликована онлайн: 21.10.2019

DOI: 10.24075/vrgmu.2019.067

Bronchial asthma (BA) is a complex disease arising from a random combination of both allergic and non-allergic factors. BA presents with a diversity of phenotypes. According to epidemiological surveillance reports, the atopic phenotype prevails in the adult population, occurring in 40 to $80 \%$ of adult asthmatic individuals. In Russia, atopic BA is diagnosed in 68-78\% of adult cases [1].

Genetic predisposition is a significant contributor to asthma development. Familial aggregation of asthma was demonstrated as early as the first half of the $20^{\text {th }}$ century. Twin studies conducted in the second half of the $20^{\text {th }}$ century estimated the heritability of the disease in the range between 36 and 95\% [2]. In the past few years, the focus has been on conducting genetic studies of BA in large clnically heterogeneous populations [3]. The analysis of candidate susceptibility genes in phenotypically homogenous cohorts allows identifying groups with similar molecular-genetic origin of the disease. A small homogeneous sample can be sufficient to detect the genetic effect of the analyzed gene [4].

Atopic disorders are regarded as immune response (type I hypersensitivity) caused and/or mediated by class IgE 
antibodies against environmental antigens. Immunological reactions underlying atopic disorders can be broken down into few major categories; some of them are implicated in the epidermal barrier dysfunction, while others regulate innate and adaptive immune responses, including lgE sensitization [5].

The list of genes reliably and positively associated with allergies and asthma includes candidate genes coding for cytokines IL4, IL10 and IL13 involved in regulating persistent allergic inflammation [6]. Russian researchers also report an association between the polymorphisms of the aforementioned genes and BA $[7,8]$.

Most research works on BA genetics focus on the genetic predisposition to this disease [9]. Few studies have looked at its course and progression. Moreover, there is evidence that genetic risk factors for BA identified so far cannot accurately predict the development of the disease or its course [10].

In the literature, the remission rate ranges from $5 \%$ in lateonset patients [11] to $65 \%$ in children and teenagers [12]. According to our estimates, the remission rate in the adults with atopic BA residing in Chelyabinsk is $22.7 \%$. A positive association with remission is observed in patients with normal $\mathrm{BMI}$, undergoing allergen-specific therapy and eliminating exposure to allergens. Other factors, such as sex, age of onset, disease duration, familial background, co-morbid seasonal or perennial rhinitis, and smoking, do not differ significantly between patients with and without remission [13].

The aim of this study was to analyze the associations between the SNPs in the genes coding for IL4 (rs2243250; C -589T), IL10 (rs1800896; G -1082A; rs1800872; C -592A), IL13 (rs20541; $\operatorname{Arg} 130 \mathrm{G} / \mathrm{n}$ ) and the development of atopic BA /its remission in the mixed sample of Chelyabinsk (South Ural) residents.

\section{METHODS}

We conducted a telephone survey of 181 individuals with atopic BA who had been patients of the allergy unit of Chelyabinsk City Clinic № 7 between 1992 and 2018. The diagnosis was established or confirmed by an allergist/immunologist based on clinical, laboratory, instrumental, and skin tests, as recommended by the Guidelines for the Diagnosis and Management of Asthma [14]. The median follow-up period was 8 years [5; 15 years].

The study included patients of both sexes aged 18 to 70 years diagnosed with mild or moderate atopic BA, with confirmed sensitivity to noninfectious allergens, who had been followed up for at least 3 years and gave consent to participate in the study. Patients with comorbid chronic obstructive lung disease, silicosis, tuberculosis, sarcoidosis, bronchiectasis or a history of previous lung surgery were excluded from the study.

Fifty-three patients aged 23-70 years underwent a physical examination; their medical history was taken, including complaints and symptoms of asthma, possible allergies and comorbidities. The patients also took the asthma control test (AST) and the bronchial reversibility test (spirometry). Screening for SNPs in interleukin genes was done using allele-specific polymerase chain reaction (PCR).
The molecular-genetic analysis was conducted at the laboratory of DNA Clinic LLC (Chelyabinsk). Genomic DNA of the patients and controls was isolated from whole-blood lymphocytes using a DNA-Express-Blood reagent kit (DNATechnology; Russia). Single nucleotide polymorphisms (SNPs) in the genes coding for IL4 (rs2243250; C-589T), IL10 (rs1800896; G-1082A; rs1800872; C-592 A), and IL13 (rs20541; Arg130G/n) were identified using an SNP-express test system (Litech; Russia) and allele-specific PCR.

Spirometry criteria for normal lung function were as follows: the absence of bronchial obstruction defined as the ratio of forced expiratory volume in $1 \mathrm{~s}$ (FEV1) to forced vital capacity (FVC) of less than 0.7 before inhalation of a bronchodilator. The bronchodilator test was considered positive if an increase in FEV1 was $12 \%$ or more after inhalation of 4 salbutamol doses and an absolute FEV1 increase was over $200 \mathrm{ml}$ [15].

There are a few definitions of asthma remission in the literature varying in length between 1 and 6 years. Some criteria for remission are based on the resolution of clinical symptoms, whereas others require rely on the objective assessment of pulmonary function [16].

Because there is no consensus as to what should be considered BA remission, we defined it as the absence of symptoms (cough, shortness of breath, sensation of suffocation, wheezing) for 1 year in the absence of baseline therapy and short-acting $\beta_{2}$ agonist therapy and the presence of normal pulmonary function observed in a negative spirometry test. Based on this definition, we stratified the patients into 2 groups: with remission of atopic BA ( $n=17 ; 14$ men and 3 women) and without remission of atopic BA ( $n=36 ; 14$ men and 22 women). The control group consisted of 30 individuals aged 23-73 years (11 men and 19 women) who had no respiratory complaints, no allergies and no family history of allergies.

The obtained data were processed in SPSS Statistics 17.0.1 (SPSS Inc; USA). The analysis was performed using descriptive statstics. Categorical variables were described as absolute and relative frequencies. A median $(\mathrm{Me})$ and an interquartile range [IQR, 25\%: 75\%] were calculated for quantitative variables. The analysis of quantitative data distribution was done using the Shapiro-Wilk test. In order to compare two means in independent samples, the Mann-Whitney $U$ test was applied. Differences were considered significant at $p<0.05$.

Allele and genotype frequencies were calculated for the studied SNPs in the candidate genes and compared to the frequencies predicted by the Hardy-Weinberg equation $\left(\chi^{2}\right.$ at $p<0.05)$. The two-tailed Fisher exact test was applied to run pairwise comparison of allele and genotype frequencies in the patients and the controls. Associations were analyzed using the odds ratio (OR) and the 95\% confidence interval $(\mathrm{Cl})$.

\section{RESULTS}

The clinical characteristics of patients with atopic BA $(n=53)$ were as follows: 36 (68\%) had polysensitization to indoor,

Table 1. Spirometry test results in patients with atopic BA remission, without remission and in the controls

\begin{tabular}{|c|c|c|c|c|}
\hline Parameter & $\begin{array}{c}\text { Patients with BA } \\
\text { remission, } n=17 \\
\text { (group 1) }\end{array}$ & $\begin{array}{c}\text { Patients without BA remission, } \\
\text { (controlled, partially controlled/uncontrolled } \\
\text { asthma) (group 2), } n=36\end{array}$ & $\begin{array}{c}\text { Controls (group 3), } \\
n=30\end{array}$ & $\begin{array}{c}p \\
\text { (groups 1-3) }\end{array}$ \\
\hline FEV1 \%, Me [Q1; Q3] & $99[89.5 ; 107.8]$ & $84[74 ; 97]$ & $104[95.5 ; 110]$ & 0.4 \\
\hline $\begin{array}{l}\text { FEV1 increase (ml) after } \\
\text { inhalation of salbutamol } \\
(400 ~ \mu g), \text { Me [Q1; Q3] }\end{array}$ & $155[0 ; 247.5]$ & $240[107.5 ; 445]$ & $167.5[82.25 ; 228.75]$ & 0.001 \\
\hline FEV1 /FVC \%, Me [Q1; Q3] & $81.5[76.3 ; 88.5]$ & $74[67 ; 79.75]$ & $83[80.5 ; 85.5]$ & 0.013 \\
\hline
\end{tabular}


Table 2. Genotype frequency distribution for SNPs in the interleukin genes in patients with atopic BA and the controls

\begin{tabular}{|c|c|c|c|c|}
\hline Genotype & Patients with atopic BA $(n=53), \%(n)$ & Control $(n=30), \%(n)$ & OR $(95 \% \mathrm{Cl})$ & $p$ \\
\hline \multicolumn{5}{|c|}{ IL4 (rs2243250) } \\
\hline$C C$ & $52.8(28)$ & $53.3(16)$ & $0.98(0.39-2.4)$ & 1.000 \\
\hline$C T$ & $43.3(23)$ & $46.6(14)$ & $0.876(0.35-2.15)$ & 0.821 \\
\hline$T T$ & $3.8(2)$ & $0(0)$ & $0.63(0.53-0.74)$ & 0.533 \\
\hline \multicolumn{5}{|c|}{ IL10 (rs1800896) } \\
\hline$G G$ & $37.7(20)$ & $43.3(13)$ & $0.79(0.31-1.97)$ & 0.647 \\
\hline$G A$ & $45.3(24)$ & $30(9)$ & $1.93(0.74-4.93)$ & 0.243 \\
\hline$A A$ & $17(9)$ & $26.6(8)$ & $0.56(0.19-1.65)$ & 0.397 \\
\hline \multicolumn{5}{|c|}{ IL10 (rs1800872) } \\
\hline$C C$ & $56.6(30)$ & $46.6(14)$ & $1.49(0.60-3.66)$ & 0.493 \\
\hline$C A$ & $37.7(20)$ & $30(9)$ & $1.41(0.54-3.68)$ & 0.632 \\
\hline$A A$ & $5.7(3)$ & $23.3(7)$ & $0.197(0.047-.832)$ & 0.031 \\
\hline \multicolumn{5}{|c|}{ IL13 (rs20541) } \\
\hline$G G$ & $55(29)$ & $56.6(17)$ & $0.924(0.37-2.27)$ & 1.000 \\
\hline$G A$ & $34(18)$ & $30(9)$ & $1.2(0.45-3.15)$ & 0.810 \\
\hline$A A$ & $11(6)$ & $13.3(4)$ & $0.83(0.21-3.21)$ & 1.000 \\
\hline
\end{tabular}

Table 3. Frequency of SNP genotypes of interleukin genes in patients with atopic BA remission and without it

\begin{tabular}{|c|c|c|c|c|c|}
\hline Genotype & $\begin{array}{l}\text { Patients with BA remission } \\
\text { (group 1) } n=17, \%(n)\end{array}$ & $\begin{array}{l}\text { Patients without BA remission } \\
\text { (group 2) } n=36, \%(n)\end{array}$ & $\begin{array}{l}\text { Control (group 3) } \\
n=30, \%(n)\end{array}$ & $\begin{array}{l}\text { OR }(95 \% \mathrm{Cl}) \\
\text { for all groups }\end{array}$ & $p$ \\
\hline \multicolumn{6}{|c|}{ IL4 (rs2243250) } \\
\hline$C C$ & $52.9(9)$ & $52.7(19)$ & $53.3(16)$ & $\begin{array}{l}1-3=1.01(0.30-3.34) \\
2-3=0.97(0.37-2.58)\end{array}$ & $\begin{array}{l}1-3=1.000 \\
2-3=1.000\end{array}$ \\
\hline$C T$ & $47.1(8)$ & $41.7(15)$ & $46.6(14)$ & $\begin{array}{l}1-3=0.98(0.29-3.24) \\
2-3=0.81(0.31-2.16)\end{array}$ & $\begin{aligned} 1-3 & =1.000 \\
2-3 & =0.804\end{aligned}$ \\
\hline$\pi T$ & $0(0)$ & $5.6(2)$ & $0(0)$ & $\begin{array}{l}1-3=- \\
2-3=0.53(0.42-0.7)\end{array}$ & $\begin{array}{l}1-3=- \\
2-3=0.497\end{array}$ \\
\hline \multicolumn{6}{|c|}{ IL10 (rs1800896) } \\
\hline$G G$ & $47.1(8)$ & $33.3(12)$ & $43.3(13)$ & $\begin{array}{l}1-3=0.86(0.26-2.84) \\
2-3=0.65(0.24-1.77)\end{array}$ & $\begin{array}{l}1-3=1.000 \\
2-3=0.452\end{array}$ \\
\hline$G A$ & $35.3(6)$ & $50(18)$ & $30(9)$ & $\begin{array}{l}1-3=0.78(0.22-2.78) \\
2-3=2.3(0.84-6.45)\end{array}$ & $\begin{array}{l}1-3=0.753 \\
2-3=0.133\end{array}$ \\
\hline$A A$ & $17.6(3)$ & $16.7(6)$ & $26.6(8)$ & $\begin{array}{l}1-3=1.69(0.38-7.5) \\
2-3=0.55(0.16-1.8)\end{array}$ & $\begin{aligned} 1-3 & =0.722 \\
2-3 & =0.375\end{aligned}$ \\
\hline \multicolumn{6}{|c|}{ IL10 (rs1800872) } \\
\hline$C C$ & $47.1(8)$ & $61.1(22)$ & $46.6(14)$ & $\begin{array}{l}1-3=0.98(0.29-3.24) \\
2-3=1.79(0.67-4.79)\end{array}$ & $\begin{array}{l}1-3=1.000 \\
2-3=0.322\end{array}$ \\
\hline$C A$ & $41.1(7)$ & $36.1(13)$ & $26.6(8)$ & $\begin{array}{l}1-3=0.61(0.17-2.12) \\
2-3=1.31(0.46-3.71)\end{array}$ & $\begin{array}{l}1-3=0.528 \\
2-3=0.794\end{array}$ \\
\hline$A A$ & $11.7(2)$ & $2.8(1)$ & $23.3(7)$ & $\begin{array}{l}1-3=2.28(0.41-12.5) \\
2-3=0.094(0.011-0.814)\end{array}$ & $\begin{array}{l}1-3=0.455 \\
2-3=0.019\end{array}$ \\
\hline \multicolumn{6}{|c|}{ IL13 Arg130 GIn (rs20541) } \\
\hline$G G$ & $52.9(9)$ & $55.6(20)$ & $56.6(17)$ & $\begin{array}{l}1-3=1.16(0.35-3.8) \\
2-3=0.95(0.36-2.53)\end{array}$ & $\begin{array}{l}1-3=1.000 \\
2-3=1.000\end{array}$ \\
\hline$G A$ & $29.4(5)$ & $36.1(13)$ & $30(9)$ & $\begin{array}{l}1-3=1.02(0.28-3.28) \\
2-3=1.31(0.47-3.7)\end{array}$ & $\begin{array}{l}1-3=1.000 \\
2-3=0.794\end{array}$ \\
\hline$A A$ & $17.7(3)$ & $8.3(3)$ & $13.3(4)$ & $\begin{array}{l}1-3=0.71(0.14-3.6) \\
2-3=0.59(0.12-2.87)\end{array}$ & $\begin{array}{l}1-3=0.692 \\
2-3=0.693\end{array}$ \\
\hline
\end{tabular}

epidermal and plant allergens; 25 (47\%) had a family history of allergies; 22 (42\%) had early-onset BA ( before 18 years of age); $41(78 \%)$ had comorbid allergic rhinitis; 38 (72\%) had mild BA, and $15(28 \%)$ had moderate BA. Lung function was normal in the group of patients with remission of atopic BA; no statistical difference in the results of the bronchodilator test was detected between this group of patients and the controls (Table 1). In patients without remission the bronchodilator test was positive, FEV1\% and FEV/FVC\% were lower than in the controls.
Genotype frequencies were calculated for the total sample of patients with atopic BA relative to the control group and for the subgroups of patients with and without remission. Linkage disequilibrium was detected for all studied loci in the control group; the studied loci were in the Hardy-Weinberg equilibrium for the group of patients with atopic BA.

The analysis of associations between the polymorphisms of interleukin genes and BA development (Table 2) revealed a statistically significant difference in the frequencies of IL10 
(rs 1800872) genotypes: genotype AA was more frequent in the control group (23.3\%) than in the group of patients with atopic $\mathrm{BA}(5.7 \%)(\mathrm{OR}=0.197 ; 95 \% \mathrm{Cl}[0.047-0.832] ; p=0.031)$ and perhaps had a protective role. No difference in frequencies were detected for other studied SNP between the patients with atopic BA and the controls.

Intergroup comparison revealed a difference in the frequency of IL10 genotypes (rs 1800872) between the patients without BA remission and the control group: the frequency of AA genotype was $2.8 \%$ vs $23.3 \%(\mathrm{OR}=0.094 ; 95 \% \mathrm{Cl}$ [0.011-0.814]; $p=0.019)$. Integral assessment of clinical and molecular-genetic data did not reveal any significant associations with BA remission (Table 3).

\section{DISCUSSION}

Previous studies of the polymorphic C-592A locus of the IL10 gene produced controversial results: some authors reported no association with predisposition to asthma [17], while others observed significant correlations [18, 19]. Previous metanalyses demonstrated an association between the polymorphism C-589T of the IL4 gene and the risk for BA in the European population [20] and another association between the polymorphism Arg130GIn of the IL13 gene and an increased risk for BA in children and adults [21-23]. According to the literature, the G-1082A polymorphism of the IL10 gene predisposes to asthma [24].

It is hypothesized that factors increasing the risk of BA may differ from those affecting its progression [25]. Perhaps, the SNPs studied in this work are not associated with the clinical prognosis of patients with BA. This question needs further investigation in larger patient samples.

\section{CONCLUSIONS}

This study presents the first data on the distribution of genotypes of the polymorphic loci C-589T (IL4), G-1082A (IL10), C-592A (IL10), and Arg130G/n (IL13) in the mixed sample of urban patients with atopic BA residing in South Ural. Considering the small sample size, the results should be interpreted with caution. So far, many genetic aspects of BA have been studied that contribute to the understanding of the pathogenesis of this multifactorial disease. Further research in this field is needed in order to adapt genetic diagnostic techniques to the clinical setting. The study of SNPs in interleukin genes can become an auxiliary tool for predicting the prognosis of the disease and encouraging patients to adhere to therapeutic regimens.

\section{References}

1. Nenasheva NM. Atopicheskaya bronhial'naya astma: rol' allergenspecificheskoj immunoterapii. Rossijskij allergologicheskij zhurnal. 2015; (6): 54-67. Russian.

2. Mathias RA. Introduction to genetics and genomics in asthma: genetics of asthma. Adv Exp Med Biol. 2014; (795): 125-55. DOI: 10.1007/978-1-4614-8603-9_9.

3. Baye TM, Martin LJ, Khurana Hershey GK. Application of genetic/ genomic approaches to allergic disorders. J Allergy Clin Immunol. 2010; 126 (3): 425-36. DOI: 10.1016/j.jaci.2010.05.025.

4. Gupta J, Johansson E, Bernstein JA, Chakraborty R, Khurana Hershey GK, Rothenberg ME, et al. Resolving the etiology of atopic disorders by genetic analysis of racial ancestry. J Allergy Clin Immunol. 2016; 138 (3): 676-99. DOI: 10.1016/j.jaci.2016.02.045.

5. Halapi E, Hakonarson $\mathrm{H}$. Recent development in genomic and proteomic research for asthma. Curr Opin Pulm Med. 2004; 10 (1): 22-30. DOI: 10.1097/00063198-200401000-00005.

6. Ober C, Hoffja S. Asthma genetics 2006: the long and winding road to gene discovery. Genes Immun. 2006; 7 (2): 95-100. DOI:10.1038/sj.gene.6364284.

7. Smolnikova MV, Freidin MB, Smirnova SV. Cytokine genes as genetic markers of controlled and uncontrolled atopic bronchia asthma. Medical Immunology (in Russia)/Meditsinskaya Immunologiya. 2017; 19 (5): 605-14. DOI: 10.15789/1563-0625-2017-5-605614. Russian

8. Karunas AS, Fedorova YY, Ramazanova NN, Galimova ES, Gimalova GF, Guryeva LL, et al. Evaluation of a role of cytokine gene polymorphisms in development of bronchial asthma in the Republic of Bashkortostan. Russian Pulmonology. 2012; (5): 37-40. Russian.

9. Marenholz I, Esparza-Gordillo J, Rüschendorf F, Bauerfeind A Strachan DP, Spycher BD, et al. Meta-analysis identifies seven susceptibility loci involved in the atopic march. Nat Commun. 2015; (6): 8804. DOI: 10.1038/ncomms9804.

10. Belsky DW, Sears MR, Hancox RJ, Harrington H, Houts R, Moffitt TE, et al. Polygenic risk and the development and course of asthma: Evidence from a 4-decade longitudinal study. Lancet Respir Med. 2013; 1 (6): 453-61. DOI: 10.1016/S2213-2600(13)70101-2.

11. Tiomisto LE, IImarinen P, Kankaanranta H. Prognosis of newonset asthma diagnosed in adult age. Respir Med. 2015; 109 (8): 944-54. DOI: 10.1016/j.rmed.2015.05.001.
12. Javed $A$, Yoo $K H$, Agarwal $K$, Jacobson RM, Li X, Juhn $Y J$, et al. Characteristics of children with asthma who achieved remission of asthma. J Asthma. 2013; 50 (5): 472-9. DOI: 10.3109/02770903.2013.787625.

13. Ignatova GL, Zhorina $\mathrm{YV}$, Abramovskikh OS, Zherebtsova IA Clinical course and remission rate in adult patients with atopic asthma in Chelyabinsk. Russian Pulmonology. 2019; 29 (3): 263-8. DOI: 10.18093/0869-0189-2019-29-3-263-268. Russian.

14. Global Initiative for asthma - NHLBI/WHO Workshop Report/ National Heart Lung Blood Institute Updated 2016. https:// ginasthma.org/ (дата обращения: 19.09.2018).

15. Chuchalin AG, Aysanov ZR, Chikina SY, Chernyak AV, Kalmanova EN. Federal guidelines of Russian Respiratory Society on spirometry. Russian Pulmonology. 2014; (6): 11-23. Russian.

16. Koh YY, Kang H, Nah KM, Kim CK. Absence of association of peripheral blood eosinophilia or increased eosinophil cationic protein with bronchial hyperresponsiveness during asthma remission. Ann Allergy Asthma Immunol. 2003; 91 (3): 297-302. DOI: 10.1016/S1081-1206(10)63533-8.

17. Karjalainen J, Hulkkonen J, Nieminen MM, Huhtala H, Aromaa A, Klaukka T, et al. Interleukin-10 gene promoter region polymorphism is associated with eosinophil count and circulating immunoglobulin E in adult asthma. Clin Exp Allergy. 2003; 33 (1): 78-83. DOl: 10.1046/j.1365-2222.2003.01577.x

18. Huang ZY, Cheng BJ, Wan Y, Zhou C. Meta-analysis of the IL10 promoter polymorphisms and pediatric asthma susceptibility. Genet Mol Res. 2016; 15 (2): gmr.15028320 DOI: 10.4238/ gmr.15028320.

19. Nie W, Fang Z, Li B, Xiu QY. Interleukin-10 promoter polymorphisms and asthma risk: a meta-analysis. Cytokine. 2012; 60 (3): 849-55. DOI: 10.1016/j.cyto.2012.08.023.

20. Tang L, Lin HG, Chen BF. Association of IL4 promoter polymorphisms with asthma: a meta-analysis. Genet Mol Res. 2014; 13 (1): 1383-94.

21. Heinzmann A, Mao X-Q, Akaiwa M, Kreomer RT, Gao PS, Ohshima K, et al. Genetic variants of IL13 signalling and human asthma and atopy. Human Molecular Genetics. 2000; 9 (4): 54959. DOI: $10.1093 / \mathrm{hmg} / 9.4 .549$.

22. Liu Z, Li P, Wang J, Fan Q, Yan P, Zhang X, et al. A meta-analysis of IL13 polymorphisms and pediatric asthma risk. Med Sci Monit. 2014; (20): 2617-23. DOI: 10.12659/MSM.891017. 
23. Mei Q, Qu J. Interleukin-13 +2044 G/A and $+1923 \mathrm{C} / \mathrm{T}$ polymorphisms are associated with asthma susceptibility in Asians: A meta-analysis. Medicine (Baltimore). 2017; 96 (51): e9203. DOI: 10.1097/MD.0000000000009203.

24. Zheng XY, Guan WJ, Mao C, Chen HF, Ding H, Zheng JP, et

\section{Литература}

1. Ненашева Н. М. Атопическая бронхиальная астма: роль аллерген-специфической иммунотерапии. Российский аллергологический журнал. 2015; ( 6): 54-67.

2. Mathias RA. Introduction to genetics and genomics in asthma: genetics of asthma. Adv Exp Med Biol. 2014; (795): 125-55. DOI: 10.1007/978-1-4614-8603-9_9.

3. Baye TM, Martin LJ, Khurana Hershey GK. Application of genetic/ genomic approaches to allergic disorders. J Allergy Clin Immunol. 2010; 126 (3): 425-36. DOI: 10.1016/j.jaci.2010.05.025

4. Gupta J, Johansson E, Bernstein JA, Chakraborty R, Khurana Hershey GK, Rothenberg ME, et al. Resolving the etiology of atopic disorders by genetic analysis of racial ancestry. J Allergy Clin Immunol. 2016; 138 (3): 676-99. DOI: 10.1016/j. jaci.2016.02.045

5. Halapi E, Hakonarson $\mathrm{H}$. Recent development in genomic and proteomic research for asthma. Curr Opin Pulm Med. 2004; 10 (1): 22-30. DOI: 10.1097/00063198-200401000-00005.

6. Ober C, Hoffja S. Asthma genetics 2006: the long and winding road to gene discovery. Genes Immun. 2006; 7 (2): 95-100. DOI:10.1038/sj.gene.6364284.

7. Смольникова М. В., Фрейдин М. Б., Смирнова С. В. Гены цитокинов как генетические маркеры атопической бронхиальной астмы с контролируемым и неконтролируемым течением. Медицинская иммунология. 2017; 19 (5): 605-14. DOI: 10.15789/1563-0625-2017-5-605-614.

8. К Карунас А. С., Федорова Ю. Ю., Рамазанова Н. Н., Галимова Е. С., Гималова Г. Ф., Гурьева Л. Л. и др. Исследование роли полиморфных вариантов генов цитокинов в развитии бронхиальной астмы в Республике Башкортостан. Пульмонология. 2012; (5): 37-40.

9. Marenholz I, Esparza-Gordillo J, Rüschendorf F, Bauerfeind A, Strachan DP, Spycher BD, et al. Meta-analysis identifies seven susceptibility loci involved in the atopic march. Nat Commun. 2015; (6): 8804. DOI: 10.1038/ncomms9804.

10. Belsky DW, Sears MR, Hancox RJ, Harrington H, Houts R, Moffitt TE, et al. Polygenic risk and the development and course of asthma: Evidence from a 4-decade longitudinal study. Lancet Respir Med. 2013; 1 (6): 453-61. DOI: 10.1016/S2213-2600(13)70101-2.

11. Tiomisto LE, IImarinen $P$, Kankaanranta $H$. Prognosis of newonset asthma diagnosed in adult age. Respir Med. 2015; 109 (8): 944-54. DOI: 10.1016/j.rmed.2015.05.001.

12. Javed $A$, Yoo $\mathrm{KH}$, Agarwal $\mathrm{K}$, Jacobson RM, Li X, Juhn $\mathrm{YJ}$, et al. Characteristics of children with asthma who achieved remission of asthma. J Asthma. 2013; 50 (5): 472-9. DOI: 10.3109/02770903.2013.787625.

13. Ипнатова Г. Л., Жорина Ю. В., Абрамовских О. С., Жеребцова И. А. Особенности течения и частота ремиссии атопической al. Interleukin-10 promoter 1082/2819/2592 polymorphisms are associated with asthma susceptibility in Asians and atopic asthma: a meta-analysis. Lung. 2014; 192 (1): 65-73.

25. Guerra S. Clinical remission of asthma: what lies beyond? Thorax. 2005; 60 (1): 5-6. DOI: 10.1136/thx.2004.033480.

бронхиальной астмы у взрослых пациентов в Челябинске. Пульмонология. 2019; 29 (3): 263-8. DOI: 10.18093/08690189-2019-29-3-263-268.

14. Global Initiative for asthma - NHLBI/WHO Workshop Report/ National Heart Lung Blood Institute Updated 2016. https:// ginasthma.org/ (дата обращения: 19.09.2018).

15. Чучалин А. Г., Айсанов З. Р., Чикина С. Ю., Черняк А. В., Калманова Е. Н. Федеральные клинические рекомендации Российского респираторного общества по использованию метода спирометрии. Пульмонология. 2014; (6): 11-23.

16. Koh YY, Kang H, Nah KM, Kim CK. Absence of association of peripheral blood eosinophilia or increased eosinophil cationic protein with bronchial hyperresponsiveness during asthma remission. Ann Allergy Asthma Immunol. 2003; 91 (3): 297-302. DOI: 10.1016/S1081-1206(10)63533-8.

17. Karjalainen J, Hulkkonen J, Nieminen MM, Huhtala H, Aromaa A, Klaukka T, et al. Interleukin-10 gene promoter region polymorphism is associated with eosinophil count and circulating immunoglobulin E in adult asthma. Clin Exp Allergy. 2003; 33 (1): 78-83. DOl: 10.1046/j.1365-2222.2003.01577.x

18. Huang ZY, Cheng BJ, Wan Y, Zhou C. Meta-analysis of the IL10 promoter polymorphisms and pediatric asthma susceptibility. Genet Mol Res. 2016; 15 (2): gmr.15028320 DOI: 10.4238/ gmr.15028320.

19. Nie W, Fang Z, Li B, Xiu QY. Interleukin-10 promoter polymorphisms and asthma risk: a meta-analysis. Cytokine. 2012; 60 (3): 849-55. DOI: 10.1016/j.cyto.2012.08.023.

20. Tang L, Lin HG, Chen BF. Association of IL4 promoter polymorphisms with asthma: a meta-analysis. Genet Mol Res. 2014; 13 (1): 1383-94.

21. Heinzmann A, Mao X-Q, Akaiwa M, Kreomer RT, Gao PS, Onshima K, et al. Genetic variants of IL13 signalling and human asthma and atopy. Human Molecular Genetics. 2000; 9 (4): 54959. DOl: $10.1093 / \mathrm{hmg} / 9.4 .549$

22. Liu Z, Li P, Wang J, Fan Q, Yan P, Zhang X, et al. A meta-analysis of IL13 polymorphisms and pediatric asthma risk. Med Sci Monit. 2014; (20): 2617-23. DOI: 10.12659/MSM.891017.

23. Mei Q, Qu J. Interleukin-13 +2044 G/A and +1923C/T polymorphisms are associated with asthma susceptibility in Asians: A meta-analysis. Medicine (Baltimore). 2017; 96 (51): e9203. DOI: 10.1097/MD.0000000000009203.

24. Zheng XY, Guan WJ, Mao C, Chen HF, Ding H, Zheng JP, et al. Interleukin-10 promoter 1082/2819/2592 polymorphisms are associated with asthma susceptibility in Asians and atopic asthma: a meta-analysis. Lung. 2014; 192 (1): 65-73.

25. Guerra S. Clinical remission of asthma: what lies beyond? Thorax. 2005; 60 (1): 5-6. DOI: 10.1136/thx.2004.033480. 